\title{
Gondwanide continental collision and the origin of Patagonia
}

\author{
R.J. Pankhurst ${ }^{1}$, C.W. Rapela ${ }^{2}$, C.M. Fanning ${ }^{3}$, M. Márquez ${ }^{4}$ \\ 1. Visiting Research Associate, NERC Isotope Geosciences Laboratory, British Geological Survey, \\ Keyworth, Nottingham NG12 5GG, U.K. \\ 2. Centro de Investigaciones Geológicas, CONICET-UNLP, Calle 1 No. 644, 1900 La Plata, Argentina \\ 3. Research School of Earth Sciences, The Australian National University, Mills Road, Canberra, ACT 200, \\ Australia \\ 4. Universidad Nacional de la Patagonia San Juan Bosco, Departamento de Geología, Kilómetro 4, \\ 9000 Comodoro Rivadavia, Argentina.
}

*Corresponding author. Tel.: +44 115 9363263; fax.: +44 1159363302.

E-Mail addresses: rjpt@nigl.nerc.ac.uk (R.J. Pankhurst), crapela@cig.museo.unlp.edu.ar (C.W. Rapela), mark.fanning@anu.edu.au (C.M. Fanning), marcelo28marquez@yahoo.com (M. Márquez).

\section{Abstract}

A review of the post-Cambrian igneous, structural and metamorphic history of Patagonia, largely revealed by a five-year programme of U-Pb zircon dating (32 samples), geochemical and isotope analysis, results in a new Late Palaeozoic collision model as the probable cause of the Gondwanide fold belts of South America and South Africa. In the northeastern part of the North Patagonian Massif, Cambro-Ordovician metasediments with a Gondwana provenance are intruded by Mid Ordovician granites analogous to those of the Famatinian arc of NW Argentina; this area is interpreted as Gondwana continental crust at least from Devonian times, probably underlain by Neoproterozoic crystalline basement affected by both Pampean and Famatinian events, with a Cambrian rifting episode previously identified in the basement of the Sierra de la Ventana. In the Devonian (following collision of the Argentine Precordillera terrane to the north), the site of magmatism jumped to the western and southwestern margins of the North Patagonian Massif, although as yet the tectonics of this magmatic event are poorly 
constrained. This was followed by Early Carboniferous I-type granites representing a subduction-related magmatic arc and mid-Carboniferous S-type granites representing crustal anatexis. The disposition of these rocks implies that the North Patagonian Massif was in the upper plate, with northeasterly subduction beneath Gondwana prior to the collision of a southern landmass represented by the Deseado Massif and its probable extension in southeastern Patagonia. This 'Deseado terrane' may have originally rifted off from a similar position during the Cambrian episode. Intense metamorphism and granite emplacement in the upper plate continued into the Early Permian. Known aspects of Late Palaeozoic sedimentation, metamorphism, and deformation in the Sierra de la Ventana and adjacent Cape Fold Belt of South Africa are encompassed within this model. It is also compatible with modern geophysical and palaeomagnetic data that do not support previous hypotheses of southward-directed subduction and collision along the northern limit of Patagonia. Subsequent Permian break-off of the subducted plate, perhaps with delamination of the lower part of the upper plate, allowed access of heat to the overlying Gondwana margin and resulted in voluminous and widespread silicic plutonism and volcanism throughout Permian and into Triassic times. Thus the new model addresses and attempts to explain three long-standing geological enigmas - the origin of the Gondwanide fold belts, the origin of Patagonia, and the cause of widespread Permian silicic magmatism (Choiyoi province) in southern South America. Differing significantly from previous models, it has new implications for the crustal structure, mineral resources, and the plant and animal distribution in this part of Gondwana, since the southern landmass would have had an independent evolution throughout the Early Palaeozoic. 


\section{Introduction}

Patagonia, conventionally considered as the continental region south of the Rio Colorado (Fig. 1), has long been recognized as differing from the rest of South America in terms of its topography, environment, flora, fauna and palaeontological record. The idea that it could have had a separate geological history (Keidel, 1925) was stimulated by the recognition of terrane accretion processes in the early 1980s. Ramos $(1984 ; 1986)$ proposed that an allochthonous (exotic) Patagonian terrane collided with cratonic South America (supercontinental Gondwana) along the Río Colorado zone in Carboniferous times. In his model, the suture (obscured by much younger sediments) formed by closure of a previously intervening ocean, due to southwest-dipping subduction beneath the North Patagonian Massif. In more recent reviews of the tectonic evolution of Patagonia, Ramos (2002, 2004) has modified this idea to include a prior Early Palaeozoic collision within the Deseado Massif, also thought to result from southward-direct subduction, prior to Late Palaeozoic collision of the combined landmass so formed with cratonic South America, as before. In partial support of these models, Devonian-Carboniferous penetrative deformation, southward-verging folds and southward-directed thrusting of supracrustal rocks of the northeastern North Patagonian Massif was described by Chernikoff and Caminos (1996) and elaborated in a detailed structural study by von Gosen (2003), who argued for Permian rather than Carboniferous crustal shortening, and possibly a northeastward-directed accretionary process.

\section{FIGURE 1 ABOUT HERE}

However, geophysical data (Chernikoff and Zappettini, 2004; Kostadinoff et al., 2005) fails to reveal any significant crustal discontinuity beneath the Río Colorado basin, and the physiographical boundary of Patagonia has been moved south to the line of the Huincul fault, which in its eastern part follows the Río Negro. Nevertheless, Kostadinoff et 
al. (2005) interpret gravimetric anomalies as indicating a basement of probable Early

Palaeozoic age extending yet farther to the south.

Moreover, plate subduction and collision should result in a recognized pattern of related magmatism, metamorphism and crustal melting. The original allochthonous Patagonia hypothesis suffered a set-back when it was shown that supposedly Carboniferous granites in the North Patagonian Massif were in fact Permian to Triassic in age (Pankhurst et al., 1992). All existing collision models lack supporting magmatic evidence for the postulated subduction and collision phases (i.e., subduction- and collisionrelated granite belts, and related metamorphism, of the right age and in the right relationship to the plate model).

We present the results of extensive study over the past six years of the ages and geochemistry of igneous and metamorphic rocks that form the pre-Mesozoic basement in Patagonia, and the provenance of some pre-Permian metasedimentary rocks. It must be emphasized that these outcrops are very small (often only a few hundred metres in plan) and sparsely distributed, due to the later extensive covering of Jurassic volcanic rocks, Cretaceous-Quaternary sedimentary basins, and Tertiary basaltic lavas. Nevertheless, the results, when combined with existing constraints, suggest that the North Patagonian Massif was already part of Gondwana in Ordovician times. In contrast, southern Patagonia seems to have belonged to an allochthonous entity that collided with the North Patagonian Massif in mid-Carboniferous times as a result of north-easterly ocean-floor subduction. The implications and consequences of this model are reviewed, especially in relation the role of continental collision in the formation of the Gondwana fold belts of South America, Africa and West Antarctica, as well as the distribution of Early Palaeozoic faunal provinces. 


\section{Analytical methods}

108

Throughout this programme, we have dated the crystallization ages of zircon in igneous and metamorphic rocks by U-Pb geochronology using SHRIMP (Sensitive HighResolution Ion Microprobe) technology at The Australian National University, Canberra (Williams, 1998). The relevant data, together with precise sample localities, are presented as a Supplementary Appendix to this paper, and are summarised on a sketch map of northern Patagonian (Fig. 2). In addition to dating metamorphic events by analysis of metamorphic overgrowths, where possible, the detrital zircons in metasedimentary rocks have been dated to provide information on provenance of the protoliths. We have also undertaken whole-rock geochemistry (Table 1) and Sr-Nd isotope analysis (Table 2) in an attempt to constrain the tectonic environment of magmatism.

\section{FIGURE 2 ABOUT HERE}

A parallel study using conventional U-Pb zircon dating has been published recently by Varela et al. (2005), in which earlier Rb-Sr and K-Ar are also reviewed (some of which must now be regarded as of dubious reliability in terms of crystallization age but, as pointed out by these authors, more probably relate to cooling and/or metamorphic effects). As indicated by Varela et al. (2005), the main events in the evolution of Patagonia are of Palaeozoic age, and metasedimentary rock units that can be ascribed to the latest Precambrian are mainly restricted to the northeastern North Patagonian Massif.

In view of the wide time-span covered by the Palaeozoic evolution of Patagonia, it is convenient to present the new results and discuss them for each of the tectonic various stages that we now recognise. The time-scale used is that of Gradstein et al. (2004)

\section{Cambrian rifting}

The oldest stable area of continental basement in southern South America is the 2000-2200 Ma Río de la Plata craton (Santos et al., 2003). The Palaeozoic sedimentary 
sequence of Sierra de la Ventana (also known as the Sierras Australes de Buenos Aires) crops out south of the proven extent of the craton, and rests on younger (Neoproterozoic) crystalline basement with crustal anatectic granite at $607 \pm 5$ Ma and I-/A-type granites at $531 \pm 4$ and $524 \pm 5$ Ma (Rapela et al., 2003). These igneous events correspond to the Brasiliano/Pampean orogenic cycles of South America farther north, and may now be thought of in terms of the final assembly of Gondwana (Veevers, 2005). The culminating phase of igneous activity here is represented by Late Cambrian ( $510 \mathrm{Ma})$ peralkaline rhyolites that were derived from lithospheric mantle, and may be interpreted as recording extensional tectonics related to rifting of this part of the Gondwana margin. Rapela et al. (2003) suggested that this rifting episode resulted in the separation of a continental fragment but could not specifically identify it within the present-day Pacific margin of West Antarctica, which is a collage of small crustal blocks (see Rapela et. al., 2003, figure 7). However, other authors agree that a Late Cambrian passive margin was established at the southern edge of Gondwana (as elsewhere, with reference to present-day geographical coordinates) along the span of the subsequent Gondwanide fold belt, e.g., Curtis (2001). Dalziel (1997) suggested that the rifted away portion was a large plateau area attached to Laurentia and that this subsequently collided much farther to the north in the Ordovician, leaving behind a fragment represented by the Argentine Precordillera.

\section{Ordovician magmatism}

In northwest Argentina, the Early Cambrian Pampean orogenic belt lies to the west of the Rio de La Plata craton, and was partially overprinted by the Early to Mid Ordovician Famatinian magmatic arc (Pankhurst et al., 1998, 2000), with intensive deformation in the Late Ordovician. The Famatinian belt has been considered as a continental marginal arc related to subduction during the approach and collision of the Precordillera terrane. However, recent geochronological and structural analysis suggests that Mesoproterozoic 
‘Grenvillian’ rocks exposed in the Western Sierras Pampeanas may have become part of autochthonous Gondwana much earlier, being accreted to the Río de la Plata craton during the Pampean event (Escayola et al., 2005; Mulcahy et al. 2005; Rapela et al. 2005a). Such a continental basement, thinned during the Late Cambrian rifting, seems a likely candidate for the crust underlying the Sierra de la Ventana and, perhaps, the northwestern part of the North Patagonian Massif (see below).

\section{FIGURE 3 ABOUT HERE}

Previous geochronological evidence has been advanced for extension of the

Famatinian magmatic belt southeastwards through La Pampa province, as far as

Chadileuvú just north of the Río Colorado and on to the Arroyo Salado area (Fig. 1) in the eastern part North Patagonian Massif (Tickyj et al., 1999; Varela et al., 1998). Our data confirm these results and establish the precise contemporaneity of magmatism in these areas, yielding indistinguishable Early Ordovician U-Pb SHRIMP ages of $474 \pm 6$ Ma and $475 \pm 5$ Ma for a (locally) early granodiorite and a late granite from Pichi Mahuida (Fig.

3a), $475 \pm 6$ and $476 \pm 4$ Ma for two granite bodies from the Arroyo Salado area, and 476

$\pm 6 \mathrm{Ma}$ for granite at Sierra Grande 25km to the SW (Fig. 3b). Amphibolite-grade metamorphism associated with the Famatinian event in the North Patagonian Massif is recorded in quartzo-feldspathic gneiss from Mina Gonzalito (Fig. 4a), where new zircon deformation characteristic of the contemporaneous Famatinian granites of northwest Argentina, but since the latter is thought to be a direct result of the collision of the 
belt, and there is no evidence for terrane collision at this time in the Patagonia region.

Geochemical and isotopic data (Tables 1, 2) show that these are equivalent to the igneous intrusions in the main part of the Famatinian belt, which are almost entirely intermediate to silicic, metaluminous, with evolved initial ${ }^{87} \mathrm{Sr} /{ }^{86} \mathrm{Sr}$ ratios $(0.707-0.710)$ and $\varepsilon N d t$ values northern areas by further collisional compression.

\section{Pre-Carboniferous sedimentation}

The country rocks of these granites in northeastern Patagonia consists of fine-grained meta-sandstones - the El Jagüelito and Nahuel Niyeu formations (see Fig. 2). González et al. (2002) argue for Cambrian deposition of the former on the basis of its relationship to the granites and its trace fossil content. Detrital zircons from the El Jaguelito Formation (Fig. 4a) have a youngest age peak at 535 Ma consistent with this assignment: although this is strictly constraint on the maximum possible age, the dominance of this peak suggests erosion from a nearby active arc and in such cases it is commonly observed that the youngest detrital zircons effectively date deposition. That for the Nahuel Niyeu Formation is slightly younger at $\sim 515 \mathrm{Ma}$ (both have a very few grains with even younger ages that probably reflect partial Pb-loss during Ordovician granite emplacement or deformation). The older provenance of both samples is typically Gondwanan with ages of 550-750 Ma (Pampean and Brasiliano) and 1000-1200 Ma ('Grenvillian’), as well as a small component of older ages, including some at $\sim 2200$ Ma. These patterns could relate to major provenance from the areas immediately to the north in Early to Mid Cambrian times, including the Río de la Plata craton (there is a very minor input of 2200-1900 Ma zircons), whereas the 'Grenvillian' component is consistent with a local basement similar to the Western Sierras Pampeanas as suggested above. The zircon cores from the Mina 
207 Gonzalito gneiss are similar, most notably in having their main provenance at 535-540 Ma

208 (Fig. 4a), also suggesting Early Cambrian deposition and generation of the gneiss from the sandstone protolith by Famatinian-age metamorphism. Thus the metapelitic rocks of the northeastern North Patagonian Massif appear to have been originally deposited as sediments on a continental shelf at the southern margin of Gondwana. Following intrusion of the Ordovician granites, the Sierra Grande sandstoneironstone formation was deposited in Silurian or Early Devonian times (Limarino et al., 1999), one of the very few such deposits known after the Precambrian era. Its probable depositional environment was a quiescent platform on a stable passive margin, with no volcanic input (Spalletti, 1993). The invertebrate marine fauna is of Malvinokaffric type, similar to that found in the Falkland Islands. Palaeomagnetic data from this formation are consistent with Permian folding, but a prior pole position consistent with stable Gondwana was used to argue against it being part of a far-travelled exotic Patagonian terrane (Rapalini, 1998). A sample of ferruginous sandstone from just outside the Sierra Grande mine has a complex detrital zircon pattern (Fig. 4a) containing all the provenance elements seen in the El Jagüelito and Nahuel Niyeu formations, as well as a youngest peak at 500 Ma. This suggests sediment derivation from the same source areas to the north, but after the eruption of the Late Cambrian rhyolites associated with rifting. One discordant grain has an apparent age of $470 \mathrm{Ma}$, but the general absence of Ordovician zircons suggests that perhaps thinned during the Late Cambrian rifting event, and affected by Famatinian plutonism in the Early Ordovician, then becoming a largely passive margin until post-Early 
232 is consistent with the observation of Kostadinoff et al. (2005) that crustal magnetic

233 signatures are continuous across the Huincul fault zone.

234

235

236

237

238

239

240

241

242

243

244

245

246

247

248

249

250

251

252

253

254

255

256

\section{Devonian magmatism}

FIGURE 5 ABOUT HERE

After the Ordovician, active magmatism reappeared at the western margin of the

North Patagonian Massif. Varela et al. (2005) have reported conventional ${ }^{238} \mathrm{U}^{206} \mathrm{~Pb}$ zircon ages of $419 \pm 27 \mathrm{Ma}(\mathrm{MSWD}=43)$ and $390.0 \pm 4.8 \mathrm{Ma}(\mathrm{MSWD}=9)$ for tonalites near San Martin de los Andes (Fig. 2), and of $348 \pm 11$ Ma (MSWD=63, possibly Carboniferous - see below) and 386.6 \pm 5.4 Ma (MSWD=9.3) for deformed leucogranites cutting schists about $50 \mathrm{~km}$ farther to the southwest. They ascribed these to a period of Devonian magmatism and migmatization associated with the Chanic orogenic event identified in the areas north of Patagonia (San Rafael, Precordillera and Sierras Pampeanas (Sims et al., 1998)). We have confirmed and refined the age of this magmatism in NW Patagonia with U-Pb zircon SHRIMP ages of $401 \pm 3$ Ma for the San Martin tonalite (Fig. 5a) and $395 \pm 4$ Ma for an undeformed granite at Lago Lolog about $10 \mathrm{~km}$ farther north (Fig. 5b). Figure 5a also illustrates ages of $371 \pm 4$ Ma for megacrystic granite near Gastre in the southwestern North Patagonian Massif and $394 \pm 4$ (recalculated from Pankhurst et al., 2001) for a similar megacrystic granite at Colán Conhue $300 \mathrm{~km}$ southeast of Bariloche (Fig. 2) which, as suggested by Varela et al. (2005), may represent further extension of this belt. At this stage, the lack of geochemical data for this suite precludes assignment of the tectonic environment of the magmatism for the porphyritic granites, but the San Martin tonalite and Lago Lolog granite have initial $\varepsilon N d t$ values of about -4 and Sm-Nd model ages of $\sim 1400 \mathrm{Ma}$ (in part recalculated from Varela et al., 2005, see Table 2), consistent with a Mesoproterozoic crustal component. If this belt, at least in its northwestern part, represents a subduction-related arc in the west at this time, it further reinforces the 
argument above that most of the North Patagonian Massif was autochthonous to

258 Gondwana during the Early Palaeozoic. The jump in the magmatic arc position across the North Patagonian Massif after mid-Ordovician times is presumably related in some way to the change of the regional tectonic scheme following collision of the Precordillera to the north.

\section{Carboniferous subduction}

I-type granitoids of Carboniferous to Permian age form the core of the Coastal

Cordillera of Chile from $33^{\circ}$ to $38^{\circ} \mathrm{S}$ where they are seen in the Cordillera de Nahuelbuta

(Fig. 1). Southeasterly extension of this belt and its metamorphosed envelope has been suggested, as far as the Piedra Santa complex near the northwestern boundary of the North Patagonian Massif (Franzese, 1995), but no supporting geochronology or geochemistry are available and until now it could not be traced any further. However, our results demonstrate the existence of a 120 km-long belt of Early Carboniferous I-type granodiorites in the eastern North Patagonian Massif, along the Cordón del Serrucho,

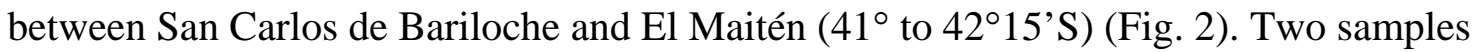
yield well-defined Early Carboniferous ( Visean) crystallization ages of $323 \pm 3$ and $330 \pm$ $4 \mathrm{Ma}$; a sample of the El Platero tonalite in the Río Chico, about $50 \mathrm{~km}$ to the southeast, gave a comparable age of $329 \pm 4$ Ma (Fig. 6a). A two-point conventional ${ }^{238} \mathrm{U}^{206} \mathrm{~Pb}$ zircon age of $321 \pm 2$ Ma has been independently reported for a sample from the same locality as MOS-043 (Varela et al., 2005). All three samples analysed, which are representative of continuous outcrop, are foliated metaluminous hornblende-biotite granitoids with low abundances of lithophile trace elements, rare earth element (REE) patterns typical of Andinotype calc-alkaline arc rocks, positive $\varepsilon N d t$ values ( +0.1 to +2.8$)$, 
such as the upper mantle (Table 1). Other authors have previously suggested Carboniferous magmatism in the western areas of the North Patagonian Massif, but mostly on the basis of imprecise Rb-Sr whole-rock errorchrons or K-Ar geochronological data (see Varela et al. 2005 for a summary).

\section{TABLES 1 and 2 ABOUT HERE}

\section{Carboniferous collision-related magmatism}

Two previously undated granite bodies in the southwestern North Patagonian Massif have yielded mid-Carboniferous (Serpuhkovian/Bashkirian) crystallization ages: $314 \pm 2$ Ma from Paso del Sapo and $318 \pm 2$ Ma from Sierra de Pichiñanes (Figs 2, 6b). These are both peraluminous S-type garnet-bearing leucogranites with high $\mathrm{SiO}_{2}$ contents, strongly depleted heavy-REE patterns, high $\mathrm{K}_{2} \mathrm{O} / \mathrm{Na}_{2} \mathrm{O}$ ratios, unradiogenic $\varepsilon N d t$ values (-5.0 to -6.0 on four samples) and relatively high initial ${ }^{87} \mathrm{Sr} /{ }^{86} \mathrm{Sr}(0.7078-0.7098)$ indicative of generation by upper crustal melting (Table 2). They have multistage Sm-Nd model ages of 1500 Ma that could represent the age of their deep crustal source region.

These results show that in the southwestern part of the North Patagonian Massif a short-lived episode of subduction was followed by crustal anatexis during the midCarboniferous. The Cordón del Serrucho runs approximately N-S (Fig. 2), but the equivalence of the El Platero tonalite suggests that the arc was orientated more NW-SE, and the S-type granites occur somewhat to the northeast of this trend line. Although the wider distribution of I- and S-type granites in Patagonia is not clear, and the lack of outcrops may unfortunately prevent further elucidation, both are typically emplaced in the overriding plate above the subduction zone before and during plate collision, respectively and their disposition thus strongly suggests subduction of an oceanic plate from the southwest. 


\section{Deformation and metamorphism}

The folded Lower Palaeozoic sequences of Sierra de la Ventana, the Cape region of

South Africa, the Falkland Islands (in their pre-Jurassic position off the eastern Cape) and the Ellsworth Mountains of West Antarctica, consist of predominantly continental shelf deposits, commencing in the mid-Cambrian, with prominent Devonian quartzite horizons, and with Early Carboniferous diamictites often interpreted as of glacial origin. In the Sierra de la Ventana, deformation includes intense penetrative folding and cleavage and subsequent large-scale folding about approximately E-W axes, together top-to-thesouthwest thrusting. Prior assumptions of a Late Permian age for deformation in both the Sierra de la Ventana and the Cape fold belt has been dependant on older publications of KAr data on illite and muscovite, together with the observation that the Permian strata at the top of the sequences have been deformed. However, there is notably less intense deformation in the Permian shales and sandstones at the top of the sequence, which were remagnetized within the fold and thrust belt, compared with the Lower Permian part of the sequence, which records stronger pre-folding magnetization northeastwards towards the foreland (Tomezzoli, 2001). Schematic cross-sections drawn by von Gosen et al. (1991) also illustrate the more intense thrust deformation in the Curamalal and Ventana groups below the level of an Early Permian unconformity. This was explained by proximity to the inferred collision zone, but could alternatively indicate that deformation began before this time but continued through the deposition of the Permian-to-Triassic Pillahuinco Group. the main collision must have occurred in mid-Carboniferous times, as originally postulated by Ramos (1984; 1986), with less intense deformation continuing into the Permian. The 
Islands and Ellsworth Mountains is mostly considered to be Permian in age, but this is also

largely based on $\mathrm{K}-\mathrm{Ar}$ dating of secondary mica in folded rocks, which can only be regarded as a minimum. Deformation certainly affects the Permian strata, but there is no time constraint on when it began.

\section{FIGURE 7 ABOUT HERE}

Intense deformation following southward thrusting of the metasedimentary basement in the northwest part of the North Patagonian Massif has been ascribed to the Permian (von Gosen, 2003). However, the main constraint for the timing of deformation here is the age of the Navarrette granodiorite which post-dates the thrust tectonics but was affected by a late stage of NW-SE compression. We present a U-Pb zircon age of $281 \pm 3$ Ma (15 points, MSWD= 2.3) which falls well within the Early Permian (Artinskian) and requires thrust tectonics to have been completed prior to this time (Fig. 7a). In the same area, Basei et al. (2002) have reported a conventional U-Pb zircon age of $300 \pm 6$ Ma for the Tardugno deformed granite, interpreted by von Gosen (2003) as a maximum age for thrust tectonics.

Carboniferous (?) tectono-metamorphism occurred in the southern and western parts of the North Patagonian Massif. Greenschist to lower amphibolite facies metamorphism was attained during peak deformation, forming extensive mylonite and ultramylonite ductile shear zones (Llambías et al., 2002 and references therein). As noted above, the igneous rocks of the Cordon del Serrucho are strongly foliated, and are associated with sheared and mylonitic schists (García-Sansegundo et al., 2005). A sample of amphibolitegrade paragneiss from south of El Maitén has zircon with metamorphic overgrowths recording events at 330, 340 and $365 \mathrm{Ma}$, and zircon cores with a major provenance at 440 Ma (Fig. 4b); it probably represents continental marginal sediments into which the Carboniferous arc was emplaced. Medium-pressure, garnet-bearing metapelitic schists, 
gneisses and migmatites of the Cushamen Formation at Río Chico (López de Luchi and

357 Cerredo, 1997), of which this is probably an equivalent, are intruded by leucogranites with $\mathrm{K}-\mathrm{Ar}$ muscovite ages of $\sim 280 \mathrm{Ma}$ and have been proposed as higher-grade derivatives of low-grade schistose rocks at Esquel (Fig. 2) (Duhart et al., 2002). Other possibly prePermian gneisses and migmatites are found at Río Collon Cura, where Varela et al. (2005) recorded a U-Pb age of $348 \pm 11$ Ma, see above, and at La Potranca, south of the Río (289 \pm 2 Ma, Fig. 7c). In contrast, the Tepuel basin in central-east Patagonia (Fig. 2, c. $43.5^{\circ} \mathrm{S}, 70.5^{\circ} \mathrm{W}$ ) has a lower section of highly deformed but low-grade Early to mid-Carboniferous metasediments, dominated by diamictites and siliciclastic rocks for which glacial, epiglacial and marine environments are documented (Limarino et al., 1999). The upper

\section{Permian magmatism} on the accuracy of their error estimates). 

both time and space, occurring across the entire width of the massif (Figs 2, 7a). The oldest confirmed Permian intrusions, some of which show evidence of deformation, include the 'Tunnel tonalite’ at Rio Chico (295 \pm 2 Ma, dated at $286 \pm 13$ Ma, MSWD= 39 by Varela et al. (2005)), the Laguna del Toro granodiorite near Gastre (294 \pm 3 Ma, previously dated as Carboniferous by Rapela et al., 1992), a weathered two-mica granite from Piedra de Aguila (290 $\pm 3 \mathrm{Ma}$ ), and leucogranite associated with migmatite at La Potranca, south of the Río Chubut (289 \pm 2 Ma). These may well have been generated during continued muscovite migmatite west of Mamil Choique (281 $\pm 2 \mathrm{Ma}$ ). Many of these rocks, for denominated the Mamil Choique or Río Chico complex, once supposedly Precambrian crystalline basement. Unlike the Carboniferous I-type granitoids, these characteristically contain zircon inherited from the older continental crust of Gondwana, as discrete grains or cores of polyphase crystals. We have not made a systematic study of the inherited components, but they typically have ages of $\sim 320$ Ma, 460 Ma, 500-650 Ma and 1000 Ma, representing the younger part of the Gondwana spectrum, with pre-Carboniferous components essentially the same as in the Cambrian metasediments of the northeastern North Patagonian Massif (Fig. 7a).

We have re-dated samples of the granites and associated volcanic rocks from La Esperanza in the northern North Patagonian Massif using the U-Pb SHRIMP zircon method (Fig. 7b). As is frequently observed, the U-Pb ages are slightly older, but consistent with the previously published Rb-Sr ages, with a total range of 246-275 Ma. Finally, An isolated outcrop of Permian granitoid from the southeastern North Patagonian Massif, the Boca de la Zanja granodiorite from near Dolavon (Fig. 2), gave $257 \pm 2$ Ma. 
The younger age range for these rocks (mostly Mid to Late Permian) than for the western and southern outcrops, suggest a northwesterly progression of magmatism during the Permian.

The composition of these Permian granitoids is quite variable (Figs 8, 9), including rocks of both metaluminous I-type and peraluminous S-type affinities (60-78\% $\left.\mathrm{SiO}_{2}\right)$, and $\varepsilon N d t$ values range from -2 (Navarrette) to -6 (Mamil Choique), and even to -10 (for the Donosa granite, La Esperanza, not dated in this study, but bracketed by the Prieto and Calvo granites according to field relationships), equivalent to source model ages 1200$1900 \mathrm{Ma}$. Their initial ${ }^{87} \mathrm{Sr} /{ }^{86} \mathrm{Sr}$ ratios range from 0.7036 to 0.7119 . Trends in the Sr-Nd isotope diagram (Fig. 9) are distinct from that exhibited by the Ordovician granitoids and the Carboniferous S-type granites; whereas the latter show a shallow trend to higher initial ${ }^{87} \mathrm{Sr} /{ }^{86} \mathrm{Sr}$ ratios, which is characteristic of upper crustal involvement, the Permian data granites of La Esperanza, that is indicative of lower crustal components. The Permian intrusions thus appear to represent a major hybrid magmatic episode involving melting throughout the crustal section.

\section{FIGURES 8 and 9 ABOUT HERE}

The North Patagonian Massif is thus a major site of Permian granitoid magmatism in southwest Gondwana. Emplacement began in earliest Permian times (c. $295 \mathrm{Ma}$ ), gradually moved towards the northwest during the Mid Permian, and reached a climax after the main deformation of the Sierra de la Ventana fold and thrust belt. We attribute the more voluminous and widespread nature of this magmatism to major access of heat to the crust following break-off of the subducted slab after a continental collision that was initiated in Carboniferous times. In principle it extends as far north as the rhyolite volcanism of Lihue Calel in La Pampa province and Lopez Lecube syenite (258 \pm 2 Ma, Fig. 7) near the Sierra 
430 de la Ventana (Fig. 1), where the alkaline character of the magmatism reflects its intraplate 431 position, and continued into the Triassic (Rapela et al., 1996). These granites can be

432 identified as the most important source so far recognised for the provenance of Permo-

433 Triassic detritus in Late Palaeozoic sedimentary rocks along this part of the Pacific margin 434 of Gondwana (Hervé et al., 2003).

\section{Discussion: a new tectonic model}

The latest information on the history of magmatism, including all new data obtained in this study, has been integrated with the sedimentary and tectonic record of the region extending from the Gondwana margin of the Sierra Ventana to southernmost Patagonia in

Fig. 10. In the remainder of this section we develop our interpretation of these data in by the Deseado Massif, and its collision with Gondwana in the mid-Carboniferous.

\section{FIGURE 10 ABOUT HERE}

Du Toit (1937) was among the first to apply the idea of continental drift to global tectonics. He recognized the essential continuity of stratigraphy and deformation in the Early Palaeozoic fold belts of Sierra de la Ventana in South America and the Cape region of South Africa, defining his ‘Samfrau Geosyncline’. Prior to the dispersion of Gondwana as separate continental fragments, these belts would have been contiguous and collinear, and presumably extended to the Early Palaeozoic sequences of the Falkland Islands and the Ellsworth Mountains of West Antarctica. They share, at least in part, semi-continuous sedimentation from Mid-Cambrian to Permian, and have several remarkable common features. With the arrival of plate tectonic theory, modern explanations of these sequences and their 'Gondwanide' deformation were sought, falling into two groups: those in which folding was ascribed to compression in a back-arc situation over a distant north-dipping subduction zone (Lock, 1980; Dalziel and Grunow, 1992; Trouw and de Wit 1999, Dalziel 
et al., 2000), and those invoking continent-continent collision (Winter, 1984; Ramos, 1984; 1986). Cawood (2005) has proposed that this deformation represents the final stage of a long-lived 'Terra Australis orogen', that began in the Neoproterozoic, was developed along the entire Gondwana margin of South America, East Antarctica, and southeast Australia, and that was primarily accretional in nature, although this would allow for the accretion of small continental terrane fragment in certain places and at various times. Since the Cape Fold Belt faces the South Atlantic ocean, there is no remaining evidence of any possible colliding continental mass, but the landmass of Patagonia lies to the south of the Sierra de la Ventana.

In Figure 11, we have attempted to demonstrate a genetic connection between the evidence presented above for Carboniferous-Early Permian collision in Patagonia with the deformation of the Gondwanide fold belts. Continental plate reconstruction of the SW margin of pre-Mesozoic Gondwana is complicated by major changes during break-up in Jurassic and Cretaceous times. These include rotation and translation of fragments such as the Falkland Plateau (Taylor and Shaw, 1989) and southern Patagonia (Vizán et al., 2005), movements on major dextral fault zones (Rapela and Pankhurst, 1992; Jacques, 2003), opening of the San Jorge and Magellanes sedimentary basins during the Cretaceous (Macdonald et al., 2003; Spalletti and Franzese, in press), growth of the westernmost areas by accretion of smaller terranes (Forsythe and Mpodozis, 1979), and crustal extension during the emplacement of granitic batholiths (Rapela et al., 2005b). Nevertheless, most recent models, e.g., Ghidella et al. (2002), concur with respect to placing the Deseado Massif much closer to the southern tip of South Africa and the northern tip of the Antarctic Peninsula outboard of southernmost Patagonia. These factors have been incorporated as far as possible into the schematic of Fig. 11. 
We suggest that the geological data summarised in this paper for the tectonic

evolution Patagonia can be best explained by mid-Carboniferous collision on the southwest side of the North Patagonian Massif, resulting from ocean closure by subduction towards the northeast beneath an autochthonous Gondwana that included at least the greater part of the North Patagonian Massif. The only possible colliding crustal block is southern Patagonia, where the main exposure of Palaeozoic basement is the Deseado Massif (Fig. 11), which has a history of Neoproterozoic sedimentation and metamorphism followed by Silurian and Devonian granite magmatism (Pankhurst et al., 2003). The strongest doubt about such a collision being the main cause of deformation of the Gondwana fold belts is the relatively small size of the exposed massif, but its subsurface extension to the southeast is suggested by geophysical data showing the presence of an offshore basement high, the Rio Chico-Dungeness Arch (Biddle et al., 1986). Even in the most recent model of accretionary rather collisional orogeny (Cawood, 2005), Patagonia is recognised as differing in nature from other accreted areas of the Gondwana margin, being classified as a 'peri-Gondwana continental assemblage'. Moreover, other continental basement areas in the West Antarctic collage could have been involved at this stage, viz. the Antarctic Peninsula, where the west coast shows evidence of Late Palaeozoic magmatic episodes superimposed on older metasedimentary rocks (Millar et al., 2002). Ultimately, even if overall plate kinematic readjustments Cawood (2005) were preferred in order to explain Gondwana-wide folding, our evidence and arguments would still suggest that southern element in the Gondwana orogeny. 
granites in the southwestern part of the North Patagonian Massif also indicate that this was

506

507

508

509

510

511

512

513 the upper plate and that ocean floor was subducted northeastwards beneath this active margin. The southern continental block is thus presumed to have had a passive margin, on which a foreland mid-Carboniferous-Early Permian basin represented by the Tepuel Group was formed before, during and after collision. Deformation was transmitted to the Palaeozoic sedimentary sequences of the Sierra de la Ventana, Cape region of South Africa, the Falkland Islands and the Ellsworth Mountains of West Antarctica as they were forced up against the back-stop of the Río de La Plata and Kaapvaal cratons, and continued into Mid Permian times. These relationships are illustrated in the schematic cross-sections of Fig. 12.

\section{FIGURE 12 ABOUT HERE}

It is apparent that the colliding block could have consisted largely of continental crust that rifted off from the Gondwana margin in Cambrian times, and that was formerly part of the Neoproterozoic precursor of Gondwana - in tectonic terms it could be described as parautochthonous rather than allochthonous. This would be consistent with the occurrence of Cambrian magmatism similar to that of the Sierra de la Ventana in both the Cape fold belt basement and beneath the Jurassic volcanic cover of Tierra del Fuego (Söllner et al., 2000; Pankhurst et al., 2003). Separation may not have been very great during the Cambrian-Carboniferous interval, which would explain the very short period of subduction (no more than 20 m.y.) preceding collision.

Large-scale crustal melting as a result of slab break-off was also the mechanism invoked by Mpodozis and Kay (1990) to explain the Permian Choiyoi magmatism, which resulted in voluminous rhyolitic volcanic rocks and granites in the Frontal Cordillera and the San Rafael Massif, central western Argentina, 28-35º S. These extensive volcanic sequences unconformably overlie marine and continental Carboniferous and Early Permian 
deposits (Caminos and Azcuy, 1996). Mpodozis and Kay (1990) postulated collision of an unidentified exotic terrane in the west ('Terrane-X'), immediately prior to slab break-off. Geological evidence for this has never been established, although there is some evidence here also for Mid Carboniferous subduction-related magmatism, e.g., the Tabaquito pluton (Llambías and Sato, 1995) which is affected by pre-Permian fragile deformation. We suggest that an alternative to the Terrane- $\mathrm{X}$ hypothesis would be propagation of a progressive rupture in the slab ('slap tear-off') initially induced by the relatively smallscale Patagonian collision proposed in this paper. Detailed chronology of the magmatism of the Choiyoi volcanism that could provide support for this idea has yet to be carried out, but we note that the time-lag between the postulated collision at about $320 \mathrm{Ma}$ and the start of Permian magmatism is comparable to that of 20-30 m.y. observed in the Himalaya after collision between India and Asia (Kohn and Parkinson, 2002).

\section{Consequences of the new model}

If the southern continental block represented by the Deseado Massif (etc.) was separated from SW Gondwana from Cambrian until Carboniferous times it could be expected to have a different early/mid Palaeozoic crustal history and basement evolution. There are already some notable distinctions (Pankhurst et al., 2003, and Fig. 10): i.e., it lacks Ordovician magmatism (although it was close to a source of Ordovician granite boulders by Permian times) and instead was the site of emplacement of Silurian S-type occurred along a pre-existing structural weakness, and thus the deep crustal structure of Patagonia south of the San Jorge basin could differ in age and origin from that to the north beneath the North Patagonian Massif. The recent discovery of Au mineralization 
associated with crust-derived Jurassic rhyolites in the Deseado Massif has not so far been repeated in similar rhyolites that cover the North Patagonian Massif, possibly as a result of its different deep geological composition. The flora and fauna developed during the Palaeozoic could also have followed significantly different evolutionary paths, depending on the geographical and climatic separation of the two continental areas. The SilurianDevonian fauna of Sierra Grande in northwestern Patagonia is of Malvinokaffric type, similar to that in South Africa, the Falkland Islands and Sierra de la Ventana (Müller, 1964; Turner, 1980, Manceñido and Damborenea, 1984), which would be easily explained if this were part if the Gondwana margin at this time.

We conclude that mid-Carboniferous collision between continental areas represented by the Deseado and North Patagonian massifs was probably responsible for initial deformation of the Gondwanide fold belts, the effects of which lasted until the Mid Permian. Early Permian slab-break-off resulted in voluminous granite magmatism. Further tests for this model could come from examination of the few remaining unstudied preMesozoic rocks, from deep seismic evidence for the nature of the deep crust of beneath the San Jorge basin, and further evaluation of the consequences of the model indicated above.

\section{Acknowledgements.}

This research was started while RJP was employed by British Antarctic Survey. The major part of the fieldwork and analytical programme was carried out with funding from CONICET, Argentina (CONICET PIP 02082 ; ANCyT PICT 07-10735) to CWR, and a Leverhulme Emeritus Fellowship (2002-2004) and NERC Small Research Grant (20042007) to RJP. Among the numerous colleagues who have assisted in developing these ideas, we especially acknowledge the help given by L.A. Spalletti and R.A. Livermore. This paper is registered as NERC Isotope Geosciences Laboratory Publication No. 723. 


\section{References}

Basei, M.A.S., Varela, R., Sato, A.M., Siga Jr., O., Llambías, E.J., 2002. Geocronología sobre rocas del Complejo Yaminué, Macizo Norpatagónico, Río Negro, Argentina. In: Cingolani, C.A., Cabaleri, N., Linares. E., López de Luchi, M.G., Ostera, H.A., Panarello, H.O. (Eds.), XV Congreso Geológico Argentino, CD-ROM, Article 152, $6 p p$.

Biddle, K.T., Uliana, M.A., Mitchum, R.M. Jr., Fitzgerald, M.G., Wright, R.C., 1986. The stratigraphical and structural evolution of the central and eastern Magallanes Basin, southern South America. In: Allen, P.A., Homewood, P. (Eds.), Foreland Basins. International Association of Sedimentology, Special Publications 8, 41-61.

Caminos, R., Azcuy, C., 1996. Fases diastróficas neopaleozoicas. In: Archangelsky, S. (Ed.), El Sistema Pérmico en la República Argentina y en la República Oriental del Uruguay. Academia Nacional de Ciencias, Córdoba, Argentina (ISSN 0325-2051), pp. 255-265.

Cawood, P.A., 2005. Terra Australis orogen: Rodinia breakup and development of the Pacific and Iapetus margins of Gondwana during the Neoproterozoic and Paleozoic. Earth-Science Reviews, 69, 249-279.

Chernikoff, C.J., Caminos, R., 1996. Estructura y relaciones estratigráficas de la Formación Nahuel Niyeu, Macizo Norpatagónico oriental, Provincia de Río Negro. Revista de la Asociación Geológica Argentina 51, 201-212.

Chernikoff, C.J., Zappettini, E.O., 2004. Geophysical evidence for terrane boundaries in South-Central Argentina. Gondwana Research 7, 1105-1116.

Curtis, M.L., 2001. Tectonic history of the Ellsworth Mountains, West Antarctica: reconciling a Gondwana enigma. Geological Society of America Bulletin 113, 939958. 
Dalziel, I.W.D., 1997. Overview. Neoproterozoic-Paleozoic geography and tectonics: review, hypothesis, environmental speculation. Geological Society of America Bulletin, 109, 16-42.

Dalziel, I.W.D., Grunow, A.M., 1992. Late Gondwanide tectonic rotations within Gondwanaland. Tectonics 11, 603-606.

Dalziel, I.W.D., Lawver, L.A., Murphy, J.B., 2000. Plumes, orogenesis, and supercontinental fragmentation. Earth Planet. Science Letters 178, 1-11.

du Toit, A.L., 1937. Our Wandering Continents. An hypothesis of continental drift. Oliver and Boyd, Edinburgh, 366 pp.

Duhart, P., Haller, M., Hervé, F., 2002. Diamictitas como parte del protolito de las metamorfitas de la Formación Cushamen en Río Chico, provincias de Río Negro y Chubut, Argentina. In: Cabaleri N., Cingolani, C.A., Linares, E., López de Luchi, M.G., Ostera, H.A., Panarello, H.O. (Eds.), Actas del XV Congreso Geológico Argentino, El Calafate, CD-ROM, Article 194, 5pp.

Escayola, M., Pimentel, M., Armstrong, R.A., 2005. A Neoproterozoic back-arc basin: SHRIMP U-Pb and Sm-Nd isotopic evidence from the Eastern Pampean Ranges, Argentina. In: Pankhurst, R.J., Veiga, G.D. (Eds.), Gondwana 12: Geological and Biological Heritage of Gondwana, Abstracts, Academia Nacional de Ciencias, Córdoba, Argentina, p.147.

Forsythe, R.D., Mpodozis, C., 1979. El archipiélago Madre de Dios, Patagonia Occidental, Magallanes: rasgos generales de la estratigrafía y estructura del basamento preJurásico Superior. Revista Geológica de Chile 7, 13-29.

Franzese, J.R., 1995. El complejo Piedra Santa (Neuquén), Argentina): parte de un cinturón metamórfico neopaleozoico del Gondwana suroccidental. Revista Geológica de Chile 22, 193-202. 
630 García-Sansegundo, J., Farias, P., Giacosa, R. E., Gallastegui, G., Heredia, N., 2005.

631

632

633

634

635

636

637

638

639

640

641

642

643

644

645

646

647

648

649

650

651

652
Structure of the North Patagonian Gondwanan basement in the Bariloche-Río

Chico-Pilcaniyeu area. In: Pankhurst, R.J., Veiga, G.D. (Eds.), Gondwana 12:

Geological and Biological Heritage of Gondwana, Abstracts, Academia Nacional de Ciencias, Córdoba, Argentina, p. 165.

Ghidella, M.E., Yañez, G., LeBreque, J.L., 2002. Revised tectonic implications for the magnetic anomalies of the western Weddell Sea. Tectonophysics 347, 65-86.

González. P.D., Poiré, P.G., Varela, R., 2002. Hallazgo de trazas fósiles en la Formación El Jagüelito y su relación con la edad de las metasedimentitas, Macizo Nordpatagónico Oriental, provincia de Río Negro. Revista de la Asociación Geológica Argentina 57, 35-44.

Gradstein, F., Ogg, J., Smith, A., 2004. A Geologic Time Scale 2004. Cambridge University Press, Cambridge, U.K., 589 pp.

Hervé, F., Fanning, C.M., Pankhurst, R.J., 2003. Detrital Zircon Age Patterns and Provenance of the metamorphic complexes of Southern Chile. Journal of South American Earth Sciences 16, 107-123.

Jacques, J.M., 2003. A tectonostratigraphic synthesis of the sub-Andean basins; inferences on the position of South American intraplate accommodation zones and their control on South Atlantic opening. Journal of the Geological Society, London 160, 703-717.

Keidel, J., 1925. Sobre el desarollo paleogeográfico del las grandes geológicos de la Argentina. Sociedad Argentina de Estudios Geológicos GAEA, Anales 4, 251-312.

Kohn, M.J., Parkinson, C.D., 2002. Petrologic case for Eocene slab beak-off during the Indo-Asian collision. Geology 30, 591-594. 
Kostadinoff, J., Gregori, D.A., Raniolo, A., 2005. Configuración geofísica-geológica del sector norte de la provincia de Río Negro. Revista de la Asociación Geológica Argentina 60, 368-376.

Limarino, C.O., Massabie, A., Rosello, E., López Gamundi, O., Page, R., Jalfin, G., 1999. El Paleozoico de Ventania, Patagonia e Islas Malvinas. In: Caminos, R. (Ed.), Geología Argentina. Instituto de Geología y Recursos Minerales, Buenos Aires, Anales 29, pp. 319-347.

Llambías, E.J., Sato, A.M., 1995. El batolito de Colangüil: transición entre orogénesis y anorogénesis. Revista de la Asociación Geológica Argentina 50, 111-131.

Llambías, E.J., Varela, R., Basei, M., Sato, A.M., 2002. Deformación y metamorfismo Neopaleozoico en Yaminué, Macizo Norpatagónico (4050`S, 67 40 W): su relación con la Fase Orogénica San Rafael y el arco de las Gondwánides. In: Cabaleri N., Cingolani, C.A., Linares, E., López de Luchi, M.G., Ostera, H.A., Panarello, H.O. (Eds.), Actas del XV Congreso Geológico Argentino, El Calafate, CD-ROM, Article 153, 6pp.

Lock, B.E., 1980. Flat-plate subduction of the Cape Fold Belt of South Africa. Geology 8, 35-39.

López de Luchi, M.G., Cerredo, M.E., 1997. Paleozoic basement of the southwestern corner of the North Patagonian Massif: an overview. VIII Congreso Geológico Chileno, Antofagasta, Actas 3, 1674-1678.

Ludwig. K.R., 1999. Isoplot/Ex, a geochronological toolkit for Microsoft Excel. Berkeley Geochronological Center Special Publication No. 1, version 2.31, 2455 Ridge Road, Berkeley, CA 94709.

Ludwig, K.R., 2000. SQUID 1.00. A user’s manual. Berkeley Geochronological Center Special Publication, 2455 Ridge Road, Berkeley, CA 94709. 
Macdonald, D., Gomez-Perez, I., Franzese, J., Spalletti, L., Lawver, L., Gahagan, L., Dalziel, I., Thomas, C., Trewin, N., Hole, M., Paton, D., 2003. Mesozoic break-up of SW Gondwana: implications for regional hydrocarbon potential of the southern South Atlantic. Marine Petroleum Geology 20, 287-308.

Manceñido, M., Damborenea, S., 1984. Megafauna de invertebrados paleozóicos y mesozóicos. In: Ramos, V. (Ed.), Geología y Recursos Naturales de la Provincia de Río Negro, IX Congreso Geológico Argentino, Bariloche, Relatorio, Asociación Geológica Argentina, Buenos Aires, pp. 413-466.

Millar, I.L., Pankhurst, R.J., Fanning, C.M., 2002. Basement Chronology of the Antarctic Peninsula: recurrent magmatism and anatexis in the Palaeozoic Gondwana Margin. Journal of the Geological Society, London 159, 145-157.

Mpodozis, C., Kay, S.M., 1990. Provincias magmáticas acidas y evolución tectónica de Gondwana: Andes Chilenos (28-31S). Revista Geológica de Chile 17, 153-180.

Mulcahy, S.R., Roeske, S.M., McClelland, W.C., Ellis, J.R., Nomade, S., Vujovich, G., 2005. Timing and nature of forearc deformation and trenchward migration of the Famatina arc during accretion of the Precordillera terrane. In: Pankhurst, R.J., Veiga, G.D. (Eds.), Gondwana 12: Geological and Biological Heritage of Gondwana, Abstracts, Academia Nacional de Ciencias, Córdoba, Argentina, p. 262.

Müller, H. von, 1964. Zur Altersfrage der eisenerzlagerstätte Sierra Grande, Río Negro in Nordpatagonien Aufgrund Neuer Fossilfunde. Solderd. Geol. Rundschau, Stuttgart, 54, 715-732.

Pankhurst, R.J., Rapela, C.W., Caminos, R., Llambías, E.J., Párica, C., 1992. A revised age for the granites of the central Somuncura batholith, North Patagonian Massif. Journal of South American Earth Sciences 5, 321-325. 
Pankhurst, R.J., Rapela, C.W., Saavedra, J., Baldo, E., Dahlquist, J., Pascua, I., Fanning, C. M., 1998. The Famatinian magmatic arc in the southern Sierras Pampeanas. In: Pankhurst, R. J., Rapela, C.W. (Eds.), The Proto-Andean Margin of Gondwana. Special Publication of the Geological Society, London 142, 343-367.

Pankhurst, R.J., Rapela, C.W., Fanning, C.M., 2000. Age and origin of coeval TTG, I- and S-type granites in the Famatinian belt of NW Argentina. Transactions of the Royal Society of Edinburgh: Earth Sciences 91, 151-168.

Pankhurst, R.J., Rapela, C.W., Fanning, C.M., 2001. The Mina Gonzalito gneiss: Early Ordovician metamorphism in northern Patagonia. Third South American Symposium of Isotope Geology, Pucón, Chile, 21-24 October 2001, CD-ROM, SERNAGEOMIN, Santiago, pp. 604-607.

Pankhurst, R.J., Rapela, C.W., Loske, W.P., Fanning, C.M., Márquez, M., 2003. Chronological study of the pre-Permian basement rocks of southern Patagonia. Journal of South American Earth Sciences 16, 27-44.

Ramos, V.A., 1984. Patagonia: ¿un continente paleozoica a la deriva? IX Congreso Geológico Argentino, San Carlos de Bariloche, Actas 2, pp. 311-325.

Ramos, V.A., 1986. Discussion of "Tectonostratigraphy, as applied to analysis of South African Phanerozoic basins” by H. de la R. Winter. Transactions of the Geological Society of South Africa 89, 427-429.

Ramos, V.A., 2002. Evolución Tectónica. In: Haller, M.J. (Ed.), Geología y Recursos Naturales de Santa Cruz. XV Congreso Geológico Argentino, El Calafate, Relatorio, Asociación Geológica Argentina, Buenos Aires, pp. 365-387.

Ramos, V., 2004. La plataforma Patagónica yu sus relaciones con la plataforma Brasileña. In: Mantesso-Neto, V., Bartorelli, A., Carneiro, C.D.R., Brito-Neves, B.B. (Eds.), 
Geologia do Continente Sul-Americano: Evolucão da Obra de Fernando Flàvio Marques de Almeida, Beca, São Paolo, Brazil, pp. 371-381.

Rapalini, A.E., 1998. Syntectonic magnetization of the mid-Palaeozoic Sierra Grande Formation: Further constraints on the tectonic evolution of Patagonia. Journal of the Geological Society, London 155, 105-114.

Rapela, C.W., Pankhurst, R.J., 1992. The granites of northern Patagonia and the Gastre Fault System in relation to the break-up of Gondwana. In: Storey, B.C., Alabaster, T., Pankhurst, R.J. (Eds.), Magmatism and the Causes of Continental Break-up. Special Publication of the Geological Society, London 68, 209-220.

Rapela, C.W., Pankhurst, R.J., Harrison, S.M., 1992. Triassic "Gondwana" granites of the Gastre District, North Patagonian Massif. Transactions of the Royal Society of Edinburgh: Earth Sciences 83, 291-304.

Rapela, C.W., Pankhurst, R.J., Llambías, E.J., Labudía, C., Artabe, A., 1996. “Gondwana” magmatism of Patagonia: Inner Cordilleran calc-alkaline batholiths and bimodal volcanic province. Third International Symposium on Andean Geodynamics, St.Malo, France, Résumés étendus, ORSTOM, Paris, pp.791-794.

Rapela, C.W., Pankhurst, R.J., Fanning, C.M., Grecco, L.E., 2003. Basement evolution of the Sierra de la Ventana Fold Belt: new evidence for Cambrian continental rifting along the southern margin of Gondwana. Journal of the Geological Society, London 160, 613-628.

Rapela, C.W., Fanning, C.M., Pankhurst, R.J., 2005a. The Río de La Plata craton: the search for its true extent. In: Pankhurst, R.J., Veiga, G.D. (Eds.), Gondwana 12: Geological and Biological Heritage of Gondwana, Abstracts, Academia Nacional de Ciencias, Córdoba, Argentina, p. 308. 
Rapela, C.W., Pankhurst, R.J., Fanning, C.M., Hervé, F., 2005b. Pacific subduction coeval with the Karoo mantle plume: the Early Jurassic Subcordilleran belt of northwestern Patagonia. In: Vaughan, A.P.M., Leat, P.T., Pankhurst, R.J. (Eds.), Terrane Processes at the Margins of Gondwana. Special Publication of the Geological Society, London 246, 217-240.

Santos, J.O., Hartmann, L.A., Bossi, J., Campal, N., Schipilov, A., Piñeiro, McNaughton, N.J., 2003. Duration of the Trans-Amazonian Cycle and its correlation within South America based on U-Pb SHRIMP geochronology of the La Plata craton, Uruguay. International Geology Review 45, 27-48.

Sims, J.P, Ireland, T.R., Camacho, A., Lyons, P., Pieters, P.E. Skirrow, R.G., Stuart-Smith, P.G., Miró, R., 1998. U-Pb, Th-Pb and Ar-Ar geochronology from the southern Sierras Pampeanas, Argentina: implications for the Palaeozoic tectonic evolution of the western Gondwana margin. In: Pankhurst, R. J., Rapela, C.W. (Eds.), The ProtoAndean Margin of Gondwana. Special Publication of the Geological Society, London 142, 259-281.

Söllner, F., Miller, H., Hervé, M., 2000. An Early Cambrian granodiorite age from the preAndean basement of Tierra del Fuego (Chile): the missing link between South America and Antarctica? Journal of South American Earth Sciences 13, 163-177.

Spalletti, L.A., 1993. An iron-bearing wave dominated siliciclastic shelf: facies analysis and paleogeographic implications (Silurian-Lower Devonian Sierra Grande Formation, southern Argentina). Geological Journal 28, 137-148.

Spalletti, L.A., Franzese, J., in press. Mesozoic palaeogeography and palaeoenvironmental evolution of Patagonia (southern South America). In: Gasparini, Z., Coria, R.A., Salgado, L. (Eds.), Patagonian Mesozoic Reptiles. Indiana University Press. 
Taylor, G.K., Shaw, J., 1989. The Falkland Islands: new palaeomagnetic data and their origin as a displaced terrane from southern Africa. American Geophysical Union, Geophysical Monograph 50, 59-72.

Tickyj, H., Llambías, E. J., Sato, A.M., 1999. El basamento cristalino de la region suroriental de la provincial de La Pampa: extension austral del orógeno famatiniano de Sierras Pampeanas. XIV Congreso Geológico Argentino, Salta, Actas 1, 160-163.

Tomezzoli, R.N., 2001. Further palaeomagnetic results from the Sierras Australes fold and thrust belt, Argentina. Geophysical Journal International 147, 356-366.

Trouw, R.A.J., de Wit, M.J., 1999. Relation between the Gondwanide orogen and contemporaneous intracratonic deformation. Journal of African Earth Sciences 28, 203-213.

Turner, J.C.M., 1980. Islas Malvinas. In: Segundo Simposio de Geología Regional Argentina, Academia Nacional de Ciencias, Córdoba, Argentina, pp. 1503-1527.

Varela, R., Basei, M.A.S., Sato, A., Siga Jr., O., Cingolani , C.A., Sato, K., 1998. Edades isotópicas $\mathrm{Rb} / \mathrm{Sr}$ y $\mathrm{U} / \mathrm{Pb}$ en rocas de Mina Gonzalito y Arroyo Salado, macizo norpatagonico atlantico, Río Negro, Argentina. X Congreso Latinoamericano de Geología, Buenos Aires, Actas, 71-76.

Varela, R., Basei, M.A.S., Cingolani, C.A, Siga Jr., O., Passarelli, C.R., 2005. El Basamento Cristalino de los Andes norpatagónicos en Argentina: geocronología e interpretación tectónica. Revista Geológica de Chile, 32, 167-182.

Veevers, J.J. 2005. Edge Tectonics (trench rollback, terrane export) of GondwanalandPangea synchronized by supercontinental heat. Gondwana Research 8, 449-456.

Vizán, H., Somoza, R., Taylor, G., 2005. Paleomagnetic testing the behaviour of Patagonia during Gondwana break-up. In: Pankhurst, R.J., Veiga, G.D. (Eds.), Gondwana 12: 

Ciencias, Córdoba, Argentina, p. 368.

800

801

802

803

804

805

806

807

808

809

810

811

812

813

814 Appendix. Summary of U-Pb SHRIMP zircon analyses.

815 Attached as Excel file for supplementary publication. doi:10.1029/2001TC901039. Argentina). Tectonophysics 185, 335-356. 179.

von Gosen, W., 2003. Thrust tectonics in the North Patagonian Massif (Argentina): implications for a Patagonian plate. Tectonics 22 (1) (2003), 1005,

von Gosen, W., Buggisch, W., Krumm, S., 1991. Metamorphism and deformation mechanisms in the Sierras Australes fold and thrust belt (Buenos Aires Province,

Williams, I.S., 1998. U-Th-Pb Geochronology by Ion Microprobe. In: McKibben, M.A., Shanks III, W.C., Ridley, W.I. (Eds.), Applications of microanalytical techniques to understanding mineralizing processes. Reviews of Economic Geology 7, 1-35.

Winter, H. de la R., 1984. Tectonostratigraphy, as applied to analysis of South African Phanerozoic basins. Transactions of the Geological Society of South Africa 87, 169- 
817 Figure 1. Sketch map of Patagonia, showing the main pre-Jurassic tectonic elements, and 818 the geographical relationship to the Sierra de la Ventana fold belt, as well as other significant basement rock exposures referred to in the text. HF= Huincul fault (Chernikoff and Zappettini, 2004).

821

Figure 2. Sketch map of the North Patagonian Massif, showing the pre-Cretaceous geology, the location of analysed samples, and the results of U-Pb zircon dating presented here (ages in Ma with 95\% c.l. errors).

825

Figure 3. New U-Pb SHRIMP zircon-dating results for Ordovician granitoids: (a) from Picchi Mahuida, Río Colorado (see Fig. 1), and (b) the northeastern North Patagonian Massif (see Fig. 2). The data (not corrected for common Pb content) are displayed in TeraWasserburg diagrams with $68.4 \%$ confidence limit error ellipses. The calculated age is the weighted mean of ${ }^{207} \mathrm{~Pb}$-corrected ${ }^{238} \mathrm{U}^{206} \mathrm{~Pb}$ ages for the white ellipses: light grey ellipses are for spots assumed to have suffered Pb-loss, and the dark grey ellipses are for those thought to contain a significant inherited component; $\mathrm{n}=$ number of points in age calculation/total number of areas analysed, $\pm 2 \sigma$ errors, MSWD $=$ Mean Square of Weighted Deviates. The derived ages of granite intrusion in these two areas are indistinguishable, and fall within the range of Famatinian granitoids in northwestern 836 Argentina.

Figure 4. (a) U-Pb zircon provenance age patterns for metasedimentary samples from NE Patagonia (see Fig. 2). The curves in the main diagrams are relative probability trends (Ludwig, 1999) based on the preferred age derived from individual measurements, which 
841 are also shown as inset histograms. For ages less than $1000 \mathrm{Ma}$, the ${ }^{238} \mathrm{U}-{ }^{206} \mathrm{~Pb}$ age is used

842 after correction for initial common $\mathrm{Pb}$ using the ${ }^{207} \mathrm{~Pb}$ measurement; for ages of $1000 \mathrm{Ma}$ 843 and more, the ${ }^{204} \mathrm{~Pb}$-corrected ${ }^{207} \mathrm{~Pb} /{ }^{206} \mathrm{~Pb}$ age is preferred. Representative portions of the 844 cathodo-luminescence for each sample are shown on the right, with individual spot ages.

845 The Mina Gonzalito gneiss zircons have Ordovician high-grade overgrowths on complex 846 nuclei that have age patterns similar to the El Jagüelito Formation schist. (b) similar plots 847 and images for the El Maitén gneiss, which has zircon overgrowths formed during latest 848 Devonian to mid-Carboniferous amphibolite-grade metamorphism.

849

Figure 5. New U-Pb SHRIMP zircon-dating results for Devonian granitoids in the western part of the North Patagonian Massif (Fig. 2). (a) Tera-Wasserburg diagrams for foliated tonalite form San Martín de los Andes, and porphyritic granites from Cáceres (southwest

853 of Gastre) and Colán Conhue, details as in Fig. 3; (b) ${ }^{204} \mathrm{~Pb}$-corrected data plotted in a Wetherill Concordia diagram for the Lago Lolog granite (since this sample contains zircons very rich in $\mathrm{U}$, the preferred age calculation is based on six concordant data points in this diagram).

857

Figure 6. New U-Pb SHRIMP zircon-dating results for Carboniferous granitoids in the southwestern part of the North Patagonian Massif (Fig. 2): (a) Tera-Wasserburg plots for three granodiorite samples representing the Early Carboniferous subduction-related arc, (b) Tera-Wasserburg diagrams for two anatectic S-type granites showing mid-Carboniferous crystallization ages. Details as for Fig. 3. 
inheritance from pre-existing Gondwana sources, including some at 470 Ma, 500-600 Ma and 1000 Ma; PAG-257 also has inherited Carboniferous zircons, (b) the granite-rhyolite complex of La Esperanza, central North Patagonian Massif. See Fig. 3 for full explanation of details, (c) two small bodies from the southern part of the North Patagonian Massif.

Figure 8. Geochemical variation plots for the Carboniferous and Permian granitoids analysed in this study, showing clear distinctions in petrogenesis. The Early Carboniferous pre-collisional group are I-type, with lithophile-element depleted signatures and primitive isotopic compositions, indicating a juvenile subduction-related source. The midCarboniferous collisional granites are lithophile-element rich and isotopically evolved (Stype), and have heavy REE depletion indicating anatexis at garnetiferous crustal depths. The widespread Permian, post-collisional granites are intermediate in composition, and have patterns compatible with variable hybridization of crust- and mantle-derived magmas.

Figure 9. Sr-Nd initial isotope composition plot for the Palaeozoic igneous rocks of Patagonia, based on the data in Table 2. The Early Carboniferous granitoids have primitive compositions largely in the long-term lithophile-element depleted quadrant, consistent with a dominant mantle-derived input. All the other granitoids have evolved initial isotope compositions indicating crustal contributions. Whereas the Ordovician and Carboniferous S-type granites follow a shallow trend suggesting young upper crustal sources with high $\mathrm{Rb} / \mathrm{Sr}$ ratios, the Permian (and Triassic) granites are far more dispersed, with the steeper trend for La Esperanza granites in particular indicating older, low Rb/Sr sources associated with deeper continental crust. G= Mina Gonzalito gneiss, M= El Maitén gneiss. 
891 Figure 10. Space-time diagram showing the pre-Mesozoic sedimentary, tectonic and magmatic history of the main regions of Patagonia and the adjacent Gondwana margin.

893 Crystallization ages of granitoids represented by ellipses are from the present study (errors 894 mostly included within the size of the symbols). Diamonds represent data from Basei et al. 895 (2002) and Varela et al. (2005), with vertical lines indicating $2 \sigma$ error bars where 896 appropriate.

897

898 Figure 11 Schematic reconstruction of SW Gondwana showing Late Palaeozoic plate 899 configurations compatible with the data presented in this paper; (a) Early Carboniferous 900 subduction stage, with the North Patagonian Massif forming part of the supercontinent 901 since Ordovician (or at least Devonian) times, separated from a 'Deseado terrane' to the 902 south, the true extent of which is unknown. Coastal areas of Chile and the Antarctic Peninsula consist of post-Carboniferous additions, but are shown as at the present day for

904 the purpose of easy identification. (b) Mid-Carboniferous collision stage, also showing the 905 extent of subsequent deformation on the Gondwanide fold belts and Permian granitoid 906 magmatism in the North Patagonian Massif. FI= Falkland Islands, EWM= Ellsworth907 Whitmore mountains crustal block.

908

909 Figure 12. Schematic cross-sections through northern Patagonia before, during and after 910 Carboniferous continental collision according to the model advanced in Figure 11. 


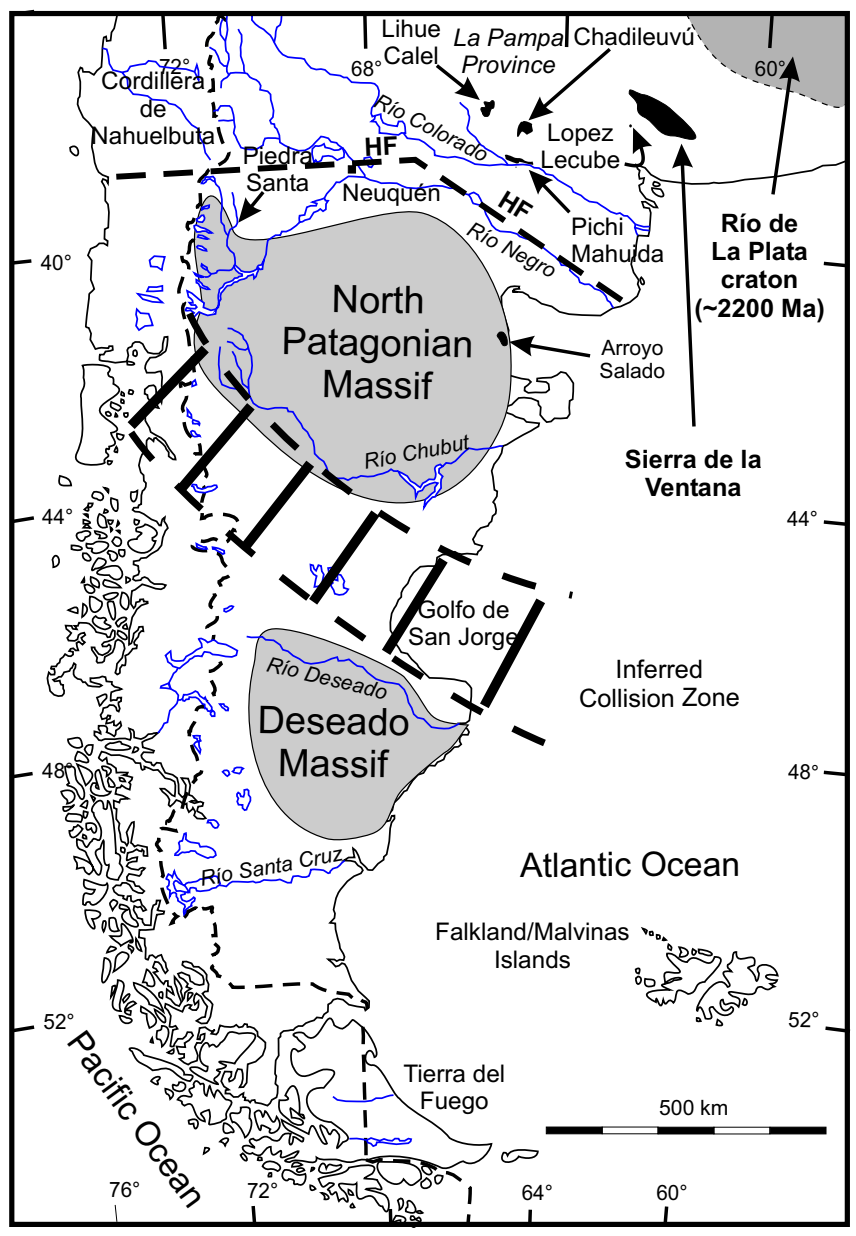

Pankhurst Fig. 1

actual size preferred (possibly column width) 


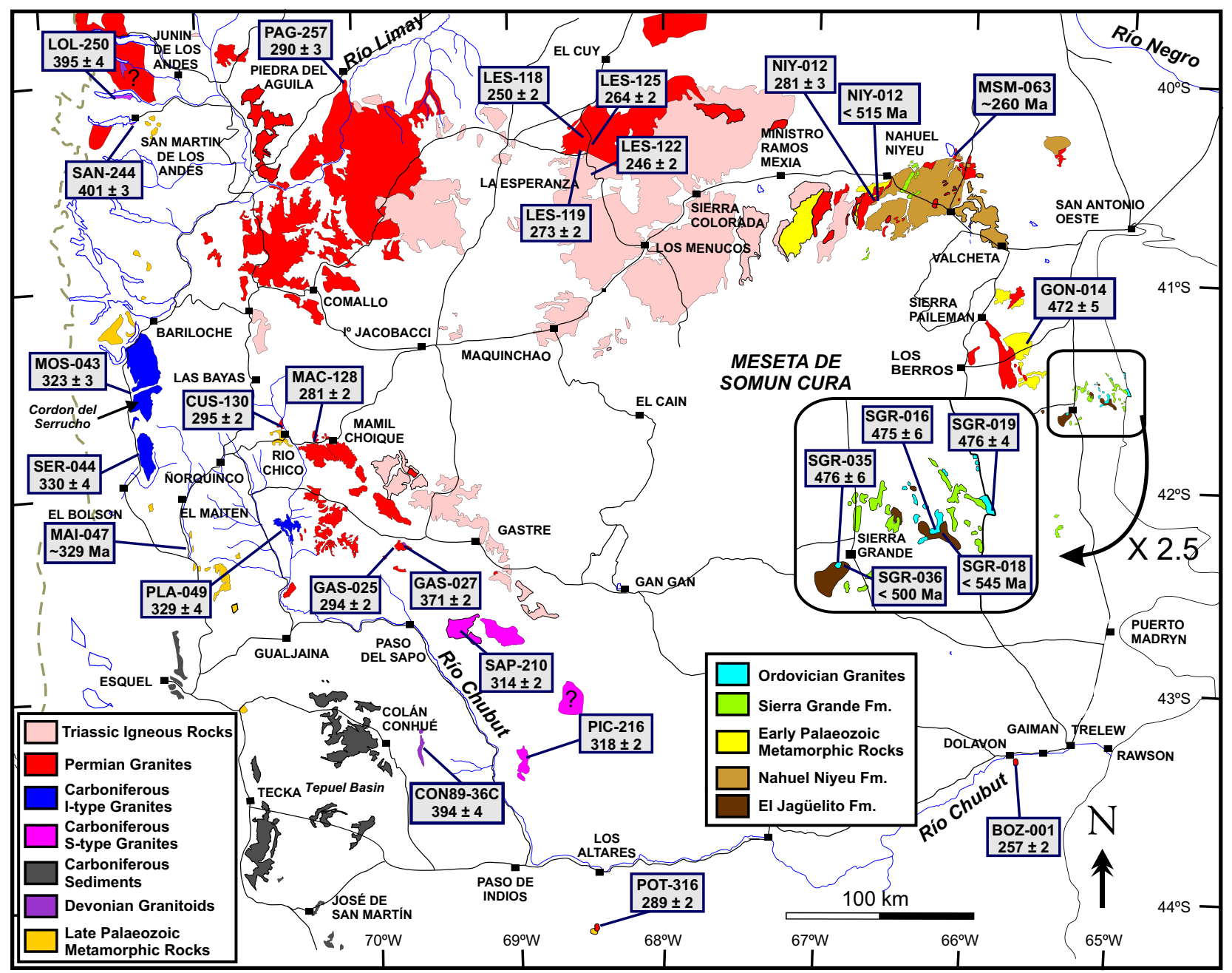

Pankhurst Fig. 2

colour print

full page width, or even rotated 90 degrees for larger size. 

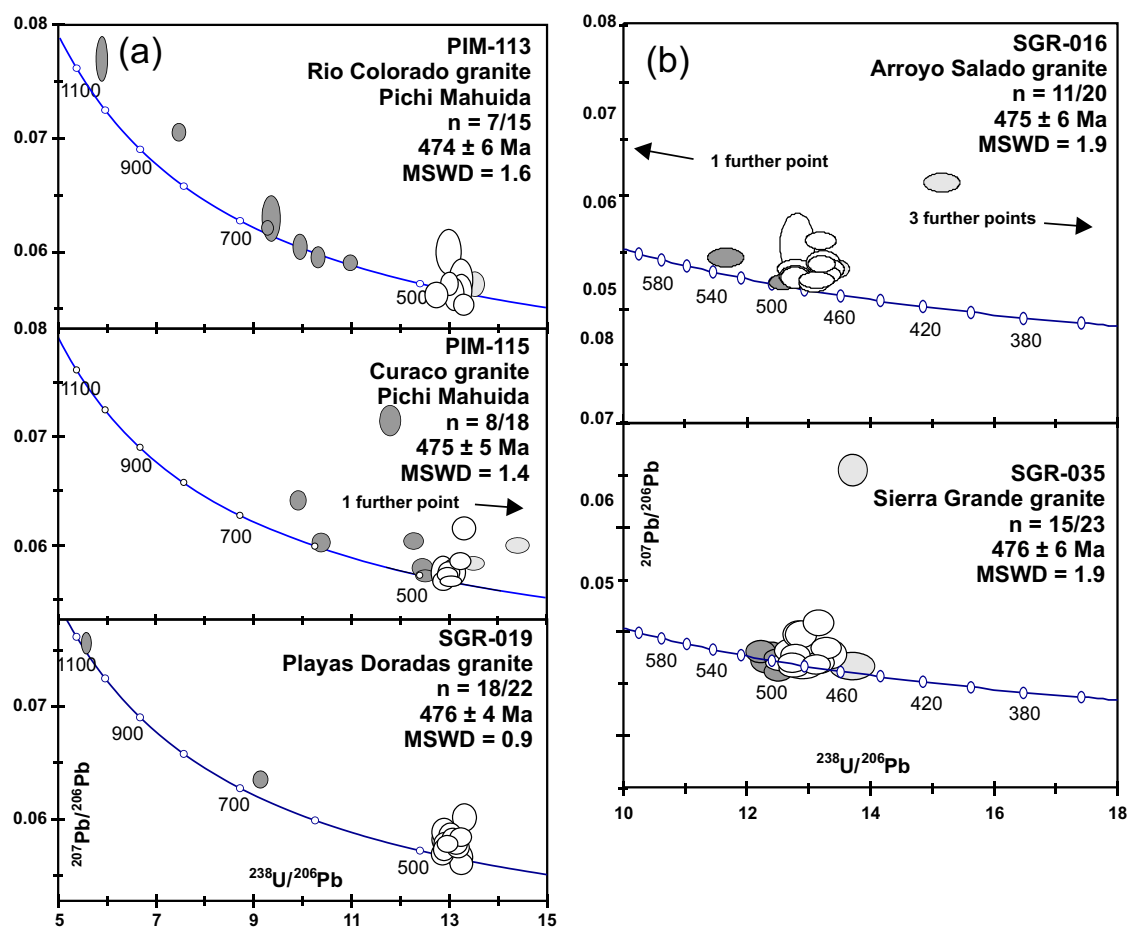

Pankhurst Fig. 3

actual size, or enlarge to page width 

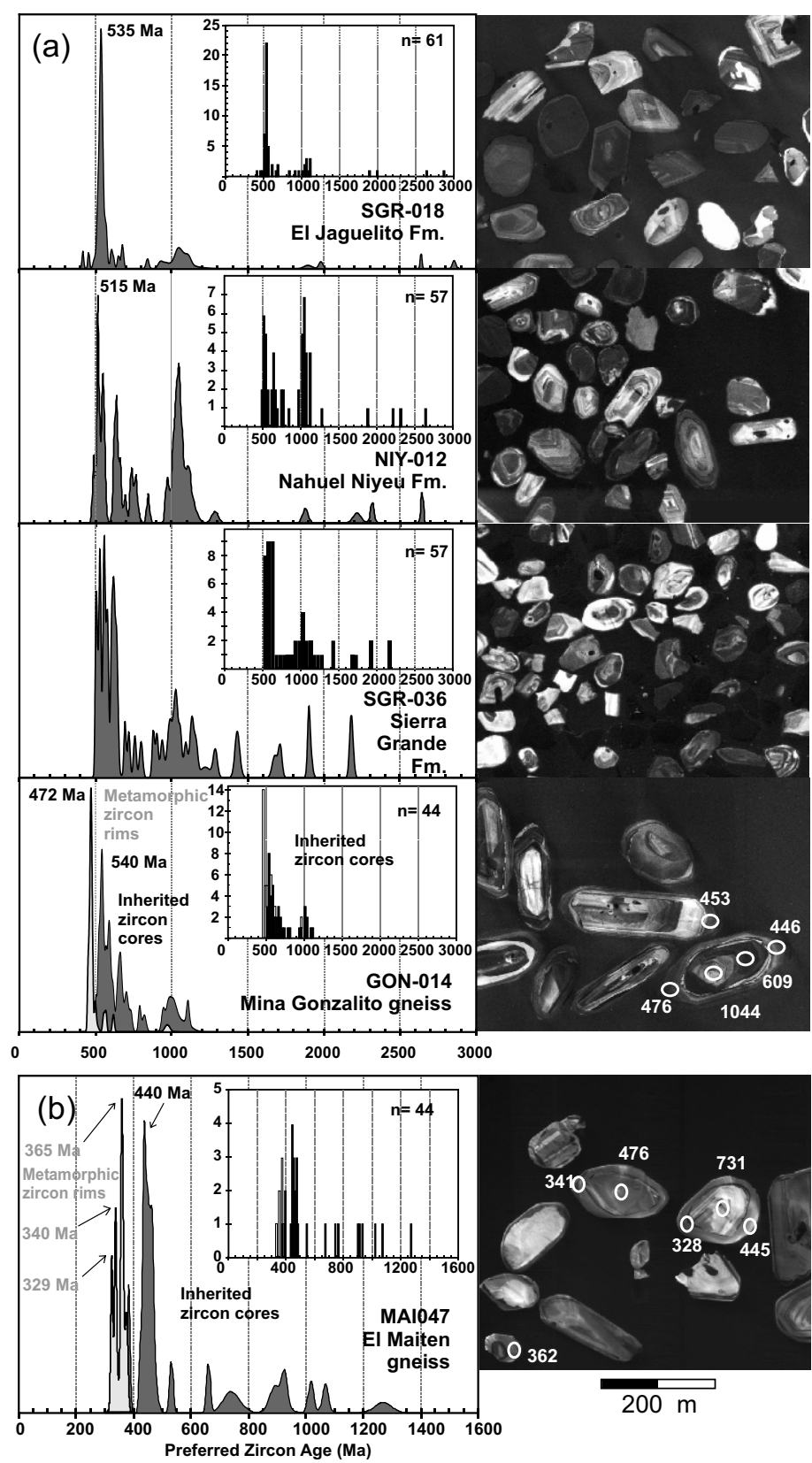

Pankhurst Fig. 4

actual size 

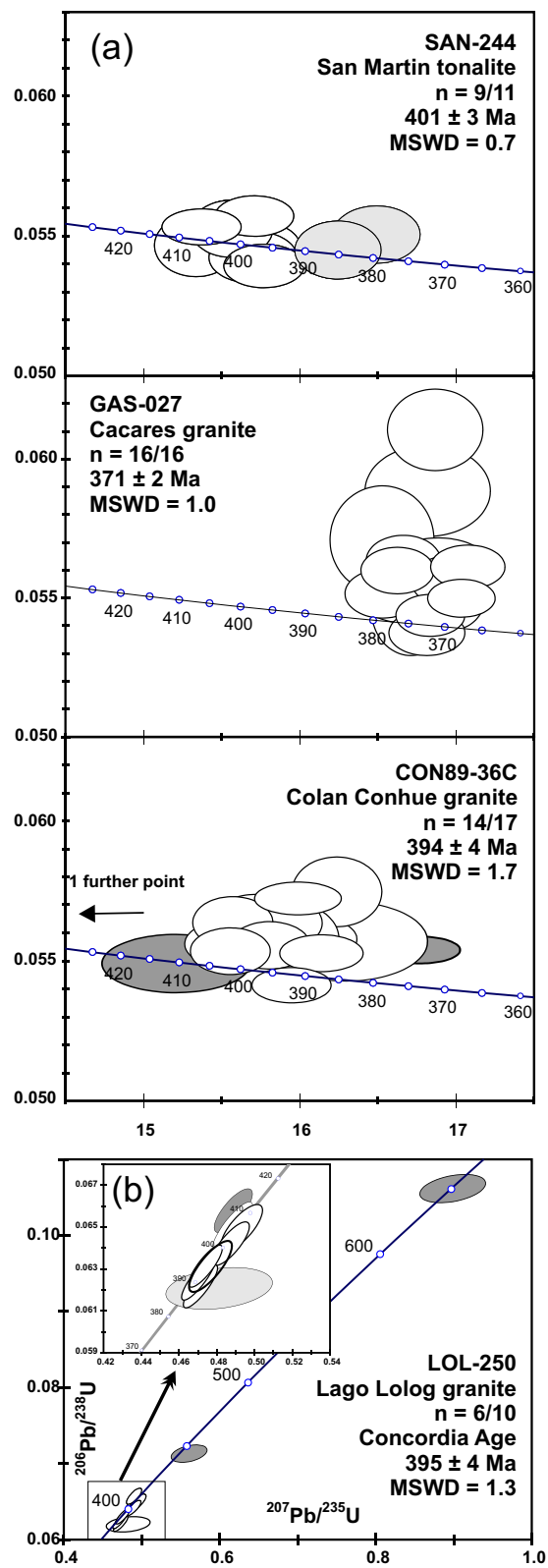

Pankhurst Fig. 5 column width 

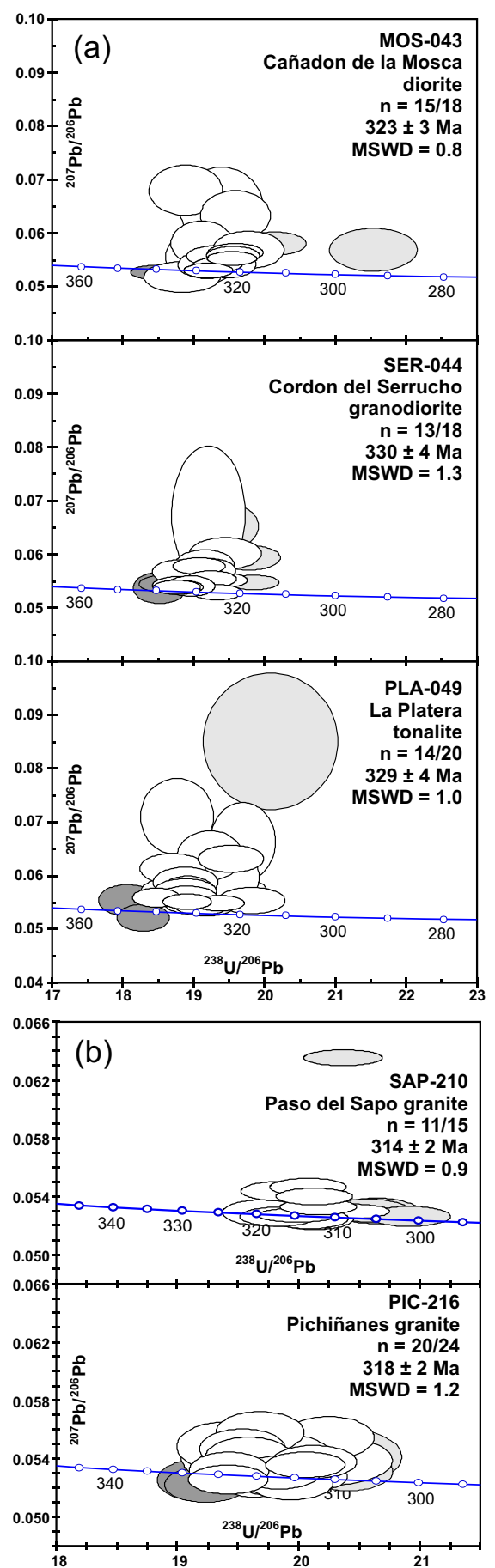

Pankhurst Fig. 6 column width 

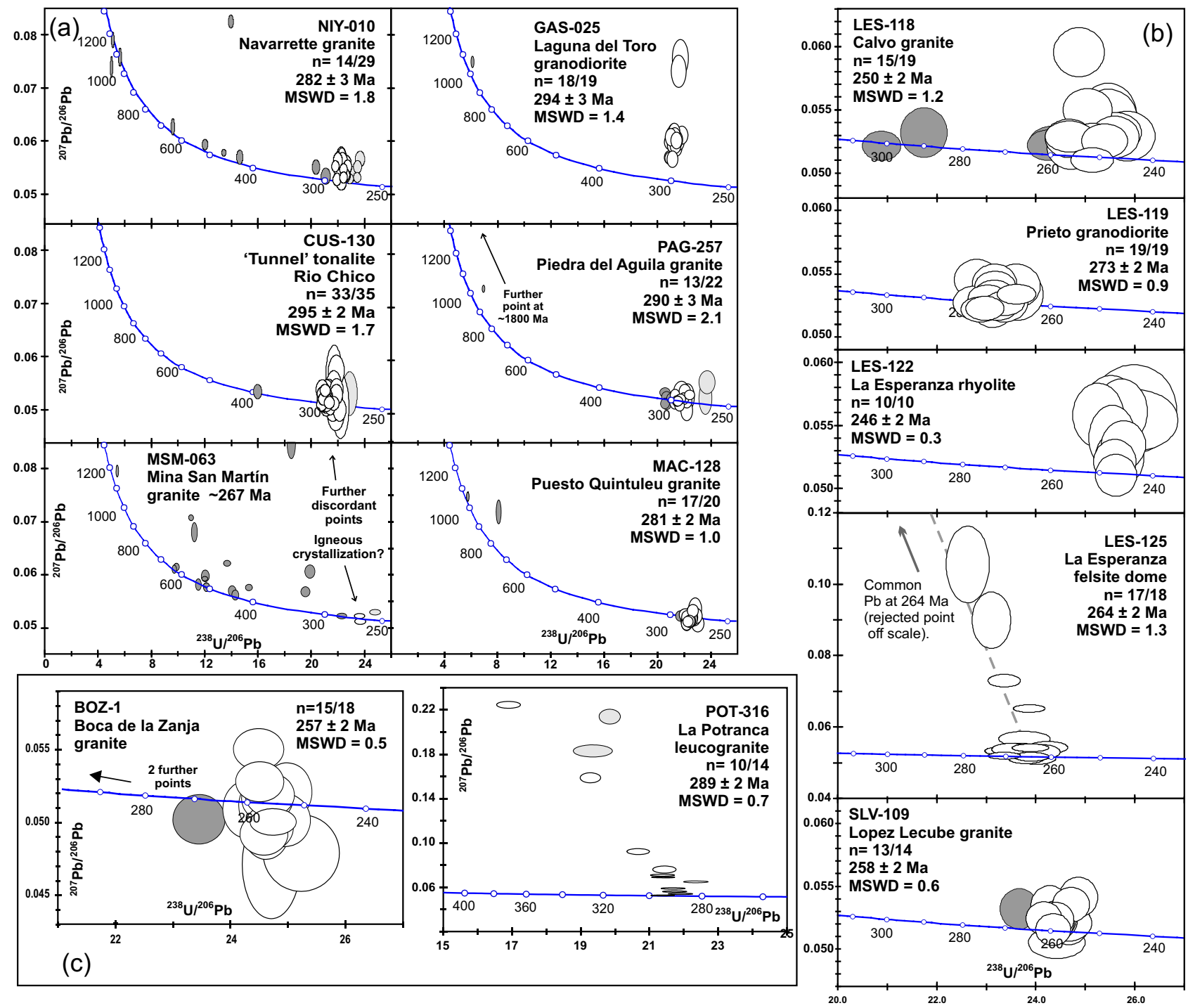

Pankhurst Fig. 7 page width 


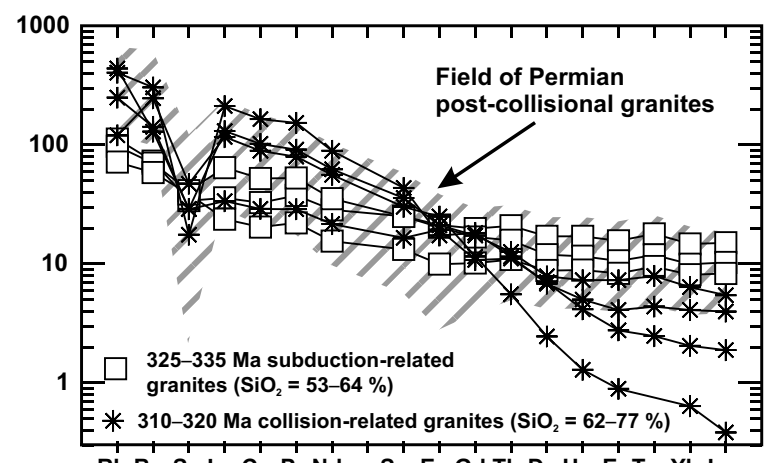

Rb Ba Sr La Ce Pr Nd Sm Eu Gd Tb Dy Ho Er Tm Yb Lu

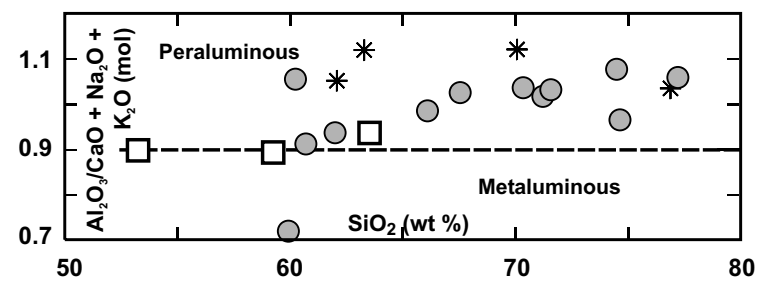

Pankhurst Fig. 8 column width 